\title{
IDENTIFIKASI BAKTERI GRAM NEGATIF DAN UJI SENSITIVITAS ANTIBIOTIK ULKUS KAKI DIABETES DI RSUP DR. M. DJAMIL PADANG
}

\author{
Dendy ${ }^{1}$, Ellyza Nasrul ${ }^{2}$, Eugeny Alia ${ }^{2}$
}

\begin{abstract}
Abstrak
Ulkus kaki diabetes merupakan komplikasi kronik diabetes melitus yang dapat menyebabkan terjadinya infeksi bakteri. Bakteri yang umum diisolasi dari infeksi ulkus kaki diabetes adalah Gram-positif dan Gram-negatif. Pemakaian antibiotik pada terapi ulkus kaki diabetes pada setiap rumah sakit berbeda sehingga terjadi perbedaan sensitivitas antibiotik. Tujuan: Mengidentifikasi bakteri gram negatif dan uji sensitivitas pada ulkus kaki diabetes di RSUP Dr M Djamil Padang. Metode: Penelitian deskriptif retrospektif telah dilakukan pada seluruh swab dari ulkus kaki diabetes di bangsal penyakit dalam yang dikultur menggunakan agar darah di Laboratorium Sentral RSUP Dr M Djamil periode Agustus 2015 sampai Juli 2016. Identifikasi bakteri dengan pewarnaan Gram dan tes biokimia. Uji sensitivitas antibiotik menggunakan metode Kirby-Bauer sesuai dengan standar CLSI. Hasil: Bakteri yang ditemukan dari swab Ulkus kaki diabetes adalah Proteus sp (36\%), Klebsiella sp (34\%), Pseudomonas sp (21\%), dan Acinetobacter sp (9\%). Proteus sp sensitif terhadap meropenem (90\%) dan resisten terhadap erithromycin (100\%). Klebsiella $s p$ resisten terhadap ampicilin (94,7\%) dan sensitif terhadap Meropenem (36.8\%). Pseudomonas sp sensitif terhadap meropenem (83.3\%) dan sebagian besar resisten terhadap antibiotik yang diuji. Acinetobacter sp sebagian besar resisten terhadap antibiotik yang diuji, hanya $40 \%$ sensitif terhadap meropenem. Simpulan: Bakteri terbanyak penyebab ulkus kaki diabetes di bangsal penyakit dalam pada periode Agustus 2015 sampai Juli 2016 adalah Proteus $s p$, yang sensitif terhadap meropenem dan resisten terhadap erithromycin.
\end{abstract}

Kata kunci: ulkus kaki diabetes, identifikasi bakteri, uji sensitivitas antibiotik

\section{Abstract}

Diabetic foot ulcers are a chronic complication of Diabetes mellitus that can be lead to bacterial infection. A common bacteria isolated from infections Diabetic foot ulcers are Gram-positive and Gram-negative. The use of antibiotics in the treatment of diabetic foot ulcers in each hospital is different so there is a difference antibiotic sensitivity. Objectives: To identifed gram negative bacteria and test sensitivity in diabetic foot ulcers in the DR. M. Djamil Hospital Padang. Methods: This research was the descriptive retrospective study on all swabs of diabetic foot ulcers in an internal medicine wards were cultured by using blood agar in the Central Laboratory of Dr M Djamil hospital Padang in period from August 2015 until July 2016. Gram staining and biochemical tests identified bacterias. Antibiotics sensitivity test were performed using Kirby-Bauer method according to CLSI standard. Results: The common bacteria found in all swabs were Proteus sp (36\%), Klebsiella sp (34\%), Pseudomonas (21\%), and Acinetobacter $s p(9 \%)$. Proteus sp sensitive to meropenem (90\%), and resistant to erithromycin (100\%). Klebsiella sp resistant to ampicilin (94.7\%) and sensitive to meropenem (36.8\%). Pseudomonas sp sensitive meropenem (83.3\%) and most resistant to the antibiotics tested. Acinetobacter sp largely resistant to antibiotics tested, only $40 \%$ sensitive to meropenem. Conclusion: The most common bacteria of diabetic foot ulcers from August 2015 until July 2016 is Proteus $s p$ that is sensitive on meropenem and resistant on erithromycin

Keywords: diabetic foot ulcers, bacterial identification, antibiotic susceptibility test 
Affiliasi penulis: 1. Dinas Kesehatan Sijunjung/Puskesmas Lubuk Tarok,Sijunjung, 2. Bagian Patologi Klinik Fakultas Kedokteran Universitas Andalas/Rumah Sakit Umum Pusat Dr. M. Djamil, Padang. Korespondensi : dendysijunjung18@gmail.com Telp: 085263230332

\section{PENDAHULUAN}

Diabetes Melitus (DM) merupakan penyakit metabolik yang menyebabkan hiperglikemia, akibat adanya defek kerja insulin, sekresi insulin, ataupun keduanya. ${ }^{1}$ Ulkus kaki diabetes merupakan komplikasi kronik diabetes melitus yang ditandai dengan ulserasi jaringan ikat dan kerusakan pada kaki disebabkan oleh hiperglikemi yang kemudian menyebabkan kelainan neuropati dan pembuluh darah sehingga mempermudah terjadinya infeksi bakteri. ${ }^{2}$ Bakteri yang paling umum diisolasi dari infeksi pada ulkus kaki diabetes adalah gram-positif cocci maupun anggota gram-negatif Enterobacteriaceae. ${ }^{3}$

Penelitian yang dilakukan oleh organisasi kesehatan dunia (WHO) pada tahun 2004 terdapat 3,4 miliar orang didunia yang mengalami diabetes melitus dan diperkirakan pada tahun 2030 akan meningkat. ${ }^{4}$ Menurut Riskesdas 2013, prevalensi DM berdasarkan wawancara di Indonesia meningkat pada tahun 2013, yaitu sebesar $2,1 \%$ jika dibandingkan dengan tahun $2007(1,1 \%){ }^{5}$

Ulkus kaki diabetik sering terjadi karena kombinasi neuropati (sensorik, motorik, otonom) dan iskemia, kondisi ini diperparah lagi dengan infeksi. ${ }^{6}$ Neuropati perifer menyebabkan hilangnya sensasi di daerah distal kaki yang mempunyai risiko tinggi untuk terjadinya ulkus kaki bahkan amputasi. ${ }^{7}$ Penyebab utama morbiditas dan mortalitas adalah tingginya angka infeksi sekitar 40-80\%. Penelitian terbaru memperkirakan bahwa risiko rawat inap dan amputasi ekstremitas bawah 155 kali lebih besar pada penderita diabetes yang mengalami infeksi ulkus kaki diabetik. ${ }^{8}$

Penelitian yang dilakukan Sulistianingsih et al (2014) di RSUD Abepura Kota Jayapura ditemukan 6 jenis bakteri penyebab infeksi pada pasien ulkus kaki diabetes yaitu Eschericia coli, Klebsiella pneumonia, Enterococcus faecalis, Staphylococcus aureus, Streptococcus uberis dan Acinetobacter baumanni. Jenis dan jumlah bakteri yang menginfeksi ulkus diabetika di RSUD Abepura adalah E. coli (38\%) dan K. pneumoniae (31\%). ${ }^{9}$ Penelitian yang dilakukan oleh Akbar et al (2014) di RSUD Arifin Achmad menemukan bakteri gram negatif yang menginfeksi ulkus yaitu: A.baumanii (34,8\%), K.pneumoniae $(26,2 \%)$, E. coli $(17,4 \%)$, E. cloacae (8,7\%), P. Stuartii (4,3\%), R. ornithinolytica (4,3\%), $P$.aeruginosa $(4,3 \%)$. Tidak ditemukan adanya bakteri gram positif. ${ }^{10}$

Pemakaian antibiotika pada terapi ulkus kaki diabetes pada setiap rumah sakit berbeda sehingga terjadi perbedaan sensitivitas antibiotik. ${ }^{11}$ Penelitian lain yang dilakukan oleh Sutjahjo (2012) tentang kuman dan kepekaan antibiotika terhadap ulkus kaki diabetes di RSUD Dr. Soetomo Surabaya dengan tingkat kepekaan tinggi terhadap bakteri pada ulkus kaki diabetes yakni Imipenem sebesar 99,2\%. ${ }^{12}$

Penelitian yang dilakukan oleh Akbar et al., (2012) di RSUD Arifin Achmad menemukan resistensi bakteri terhadap antibiotik didapatkan amoxicillin dan ampicillin memiliki nilai sensitivitas terendah yaitu sebesar $0 \%$ diikuti cefotaxime, ciprofloxacin, dan trimethoprim/sulfamethoxazole sebesar 21,7\%. Sedangkan sensitivitas tertinggi yaitu meropenem $100 \%$, imipenem, amikacin, dan colistin masingmasing $95,6 \%$, diikuti ertapenem sebesar $91,3 \% .^{10}$

Penelitian yang dilakukan oleh Kahuripan et al (2009) di RSUD Dr. H. Abdul Moeloek Lampung, menemukan jenis antibiotik yang masih sensitif terhadap isolat pus pasien ulkus kaki diabetes yaitu: meropenem (10,38\%) dan netilmisin (10,71\%). ${ }^{13}$

Pelaporan bakteri dan uji sensitivitas sangat penting dilakukan secara berkala setiap tahun terutama terhadap pasien di bangsal penyakit dalam sebagai pedoman klinisi dalam memberikan antibiotik yang tepat dan mencegah penyebaran infeksi lebih lanjut. RSUP. Dr. M. Djamil Padang sebagai pusat rujukan nasional sebaiknya memiliki data mengenai pengidentifikasian bakteri gram-negatif dan uji sensitivitas terhadap antibiotik pada pasien ulkus kaki diabetes yang diperbaharui setiap tahun dan diinformasikan kepada klinisi di bangsal penyakit dalam. 
Penelitian ini bertujuan untuk mengidentifikasi bakteri gram-negatif dan uji sensitivitas antibiotik pada ulkus kaki diabetes di bangsal penyakit dalam RSUP. Dr. M. Djamil Padang periode Agustus 2015 sampai Juli 2016.

\section{METODE}

Penelitian ini adalah studi deskriptif retrospektif yang dilakukan di Laboratorium Sentral RSUP. Dr M Djamil Padang dari Agustus 2015 sampai Juli 2016. Subyek penelitian adalah kultur positif dari swab yang menderita ulkus kaki diabetes selama periode Agustus 2015 sampai Juli 2016.

\section{HASIL}

Telah dilakukan penelitian terhadap 56 swab dari pasien ulkus kaki diabetes yang dirawat di penyakit dalam periode Agustus 2015 sampai Juli 2016. Bakteri yang ditemukan adalah Proteus $s p 20$ (36\%), Klebsiella sp 19 (34\%), Pseudomonas sp 12 (21\%) dan Acinetobacter sp 5 (9\%) (Gambar 1).

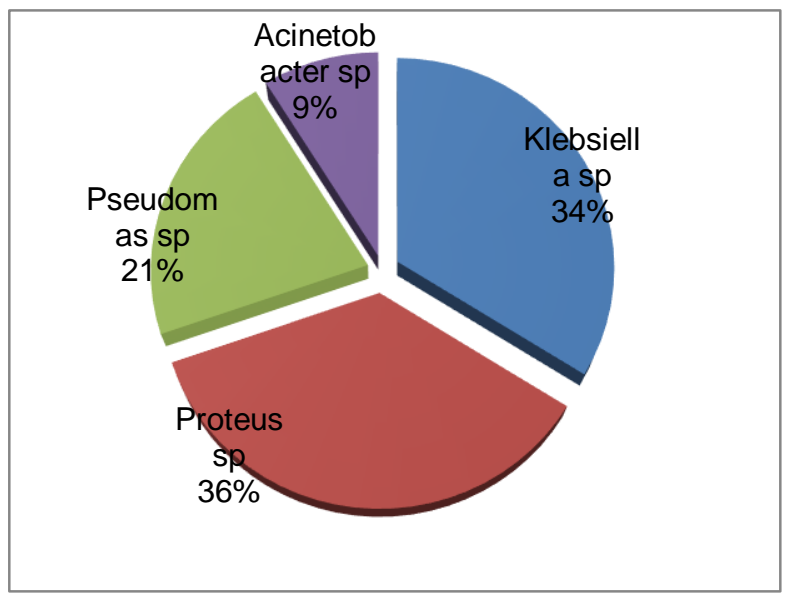

Gambar 1. Hasil kultur swab pasien ulkus kaki diabetes yang dirawat di bangsal penyakit dalam RSUP Dr. M. Djamil Padang periode Agustus 2015 sampai Juli 2016

Hasil uji sensitivitas terhadap Proteus sp pada spesimen ulkus kaki diabetes yang dirawat di bangsal penyakit dalam periode agustus 2015 sampai juli 2016 didapatkan bahwa kuman ini sensitif terhadap meropenem (90\%), ceptazidime (70\%), ciprofloxacin (60\%), fosfomicin (60\%). Resistensi kuman proteus sp didapatkan tertinggi terhadap erithromycin (100\%), amoxycilin (85\%). (Gambar 2).

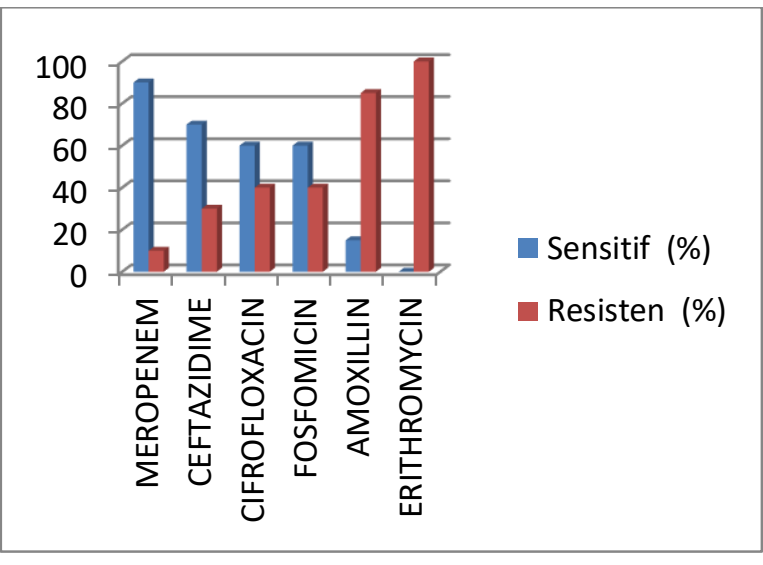

Gambar 2. Hasil uji sensitivitas Proteus sp terhadap beberapa antibiotik

Hasil uji sensitivitas terhadap Klebsiella $s p$ pada spesimen ulkus kaki diabetes yang dirawat di bangsal penyakit dalam periode agustus 2015 sampai juli 2016 didapatkan bahwa kuman ini sebagian besar resisten terhadap ampicilin, amoxylin, erithromycin, cefotaxime, cefoperazone sebesar $(94,7 \%)$.

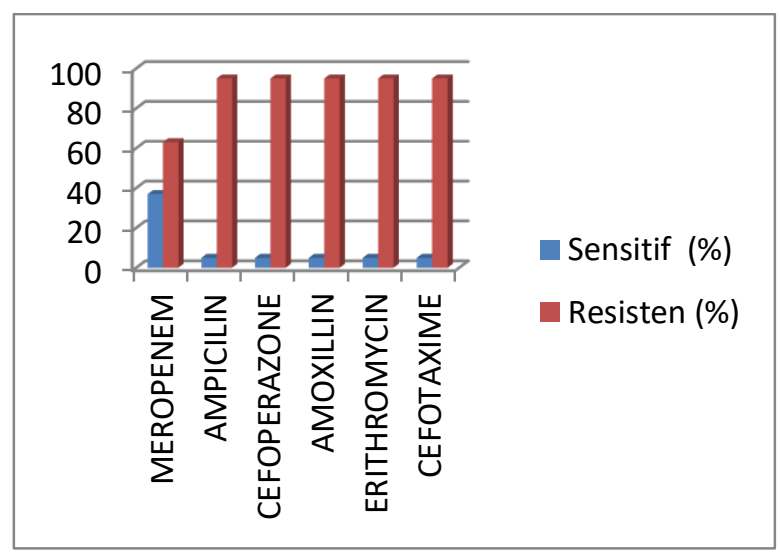

Gambar 3. Hasil uji sensitivitas Klebsiella sp terhadap beberapa antibiotik

Hasil uji sensitivitas terhadap Pseudomonas sp pada spesimen ulkus kaki diabetes yang dirawat di bangsal penyakit dalam periode agustus 2015 sampai juli 2016 didapatkan bahwa kuman ini sebagian resisten terhadap antibiotik yang diuji, tetapi beberapa masih sensitif terhadap Meropenem (83.3\%), Ciprofloxacin (75\%), Gentamycin dan Levofloxacin $(66,7 \%)$. (Gambar 4) 


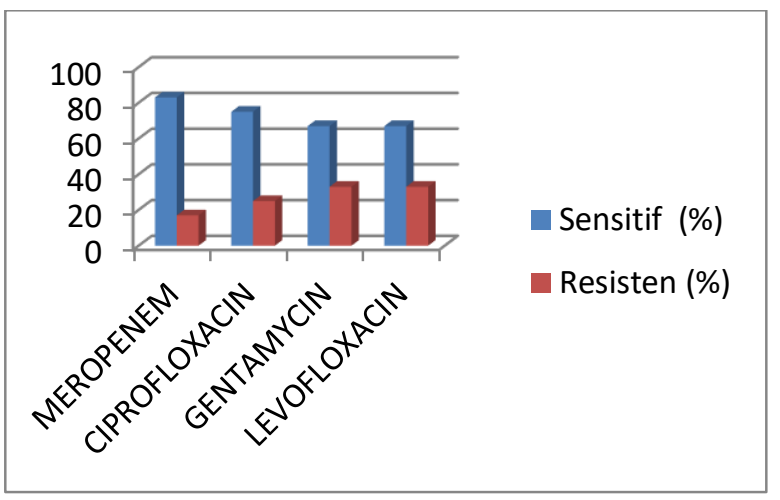

Gambar 4. Hasil uji sensitivitas Pseudomonas sp terhadap beberapa antibiotik

Hasil uji sensitivitas terhadap Acinetobacter sp pada spesimen ulkus kaki diabetes yang dirawat di bangsal penyakit dalam periode agustus 2015 sampai juli 2016 didapatkan bahwa kuman ini resisten terhadap ampicilin, amoxycilin, chloramphenicol, erithromycin, cefotaxime, dan Ciprofloxacin sebesar (100\%). (Gambar 5).

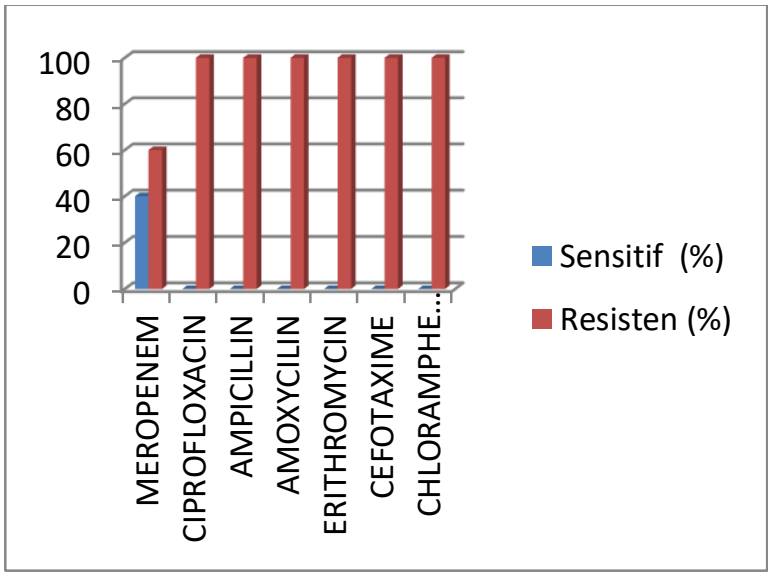

Gambar 5. Hasil uji sensitivitas Acinetobacter $s p$ terhadap beberapa Antibiotik

\section{PEMBAHASAN}

Bakteri penyebab ulkus kaki diabetes terbanyak pada pasien yang dirawat di bangsal penyakit dalam berdasarkan hasil kultur swab pada periode Agustus 2015 sampai Juli 2016 adalah Proteus sp. Bakteri lain yang ditemukan pada periode Agustus 2015 sampai Juli 2016 adalah Klebsiella sp, Pseudomonas sp, dan Acinetobacter sp.

Penelitian oleh Banashankari et al (2012) didapatkan bakteri gram negatif terbanyak penyebab ulkus kaki diabetes adalah Proteus sp (18\%). ${ }^{14}$ Hasil tersebut sama dengan yang didapatkan peneltian ini.

Penelitian yang dilakukan di RSU Dr. Soetomo Surabaya tahun 2012, didapatkan bakteri yang terbanyak adalah Staphylococcus sp (25\%), Pseudomonas sp (18\%), disusul acitenobacter $s p$, Escherichia sp, dan Klebsiella sp, yaitu masingmasing sebesar $12 \% .{ }^{15}$ Hasil penelitian tersebut berbeda dengan yang didapatkan oleh peneliti pada periode Agustus 2015 sampai Juli 2016.

Hasil penelitian ini juga berbeda dengan penelitian sebelumnya yang dilakukan di laboratorium mikrobiologi RSUP dr. M. Djamil periode 2011-2013 yang mendapatkan Klebsiella sp (34\%) sebagai penyebab terbanyak sebagai penyebab ulkus kaki diabetes. ${ }^{16}$

Hasil uji sensitivitas antibiotik pada penelitian ini terhadap Proteus sp periode Agustus 2015 - Juli 2016 didapatkan bahwa bakteri ini sensitif terhadap meropenem (90\%). Hasil ini hampir sama dengan yang diteliti oleh Akbar et al di RSUD Arifin Achmad Pekanbaru periode 2012. ${ }^{10}$

Antibiotika yang sekarang paling efektif pada bakteri gram negatif adalah impinem dan meropenem. ${ }^{17}$ Antibiotika golongan sefalosporin dari hasil penelitian lain didapatkan sudah resisten, diikuti ampisilin, siprofloksasin, gentamisin, dan aztreonam terhadap bakteri gram negatif pada ulkus diabetik. ${ }^{18}$ Hasil ini hampir sama dengan yang didapatkan dalam penelitian ini.

Penelitian ini mendapatkan nilai sensitivitas tertinggi pada ulkus kaki diabetes untuk bakteri gram negatif pada meropenem sebesar 90\%. Hasil penelitian ini hampir sama dengan yang didapatkan Mehta et al (2014) di Gujarat didapatkan nilai sensitivitas tertinggi pada imipenem sebesar $100 \%{ }^{18}$

Pappu et al (2011) mendapatkan nilai sensitivitas tertinggi terhadap ulkus diabetes untuk bakteri gram negatif pada amoksisilin klavulanat dan cefoperazon sulbaktam. ${ }^{19}$ Hasil penelitian tersebut berbeda dengan yang didapatkan peneliti.

Resistensi bakteri terhadap antibiotik kemungkinan besar disebabkan penggunaan yang luas dari antibiotik tersebut dengan dosis dan lama pemberian yang tidak rasional serta tidak terkontrol. 
perkembangan resistensi bakteri terhadap antibiotika juga dipengaruhi oleh intensitas pemaparan. Penggunaan antibiotik yang terkendali sangat penting untuk mencegah resistensi bakteri. ${ }^{20}$

\section{SIMPULAN}

Bakteri terbanyak yang ditemukan pada pasien ulkus kaki diabetes di bangsal penyakit dalam berdasarkan hasil kultur swab pada periode Agustus 2015 sampai Juli 2016 adalah Proteus sp yang sensitif terhadap meropenem dan resisten terhadap erithromycin.

\section{UCAPAN TERIMAKASIH}

Terimakasih kepada semua pihak yang turut membantu hingga selesainya penelitian ini.

\section{DAFTAR PUSTAKA}

1. American Diabetes Association. Standards of medical care in diabetes. Diabetes Care. 2013;36 (Suppl1): S4-S10.

2. Waspadji S. Kaki Diabetes. Dalam: Sudoyo AW, Setiyohadi B, Alwi I, Simadibrata M, Setiati S, editor (penyunting). Buku Ajar IImu Penyakit Dalam. Edisi ke-5. Jakarta: Fakultas Kedokteran Universitas Indonesia; 2009. hlm.1911-4.

3. Akhi MT, Ghotaslou R, Asgharzadeh M, Varschochi AM, Pirzadeh T, Memar MY, et al. Bacterial etiology and antibiotic susceptibility pattern of diabetic foot infections in Tabriz Iran. GMS Hygiene and Infection Control. 2015;10:1-6.

4. World Health Organization (WHO). Diabetes. Geneva: WHO; 2013.

5. Badan Penelitian dan Pengembangan Kesehatan. Laporan hasil riset kesehatan dasar tahun 2013. Jakarta: Kementerian Kesehatan RI; 2013.

6. Bilous R, Donelly R. Buku pegangan diabetes. Edisi ke- 4. Jakarta: Bumi Medika; 2014.

7. Perkumpulan Endokrinologi Indonesia (PB Perkeni). Konsensus pengendalian dan pencegahan diabetes mellitus tipe 2 di Indonesia 2011. Jakarta: PB Perkeni; 2011.
8. Richard JL, Sotto A, Lavigne JP. New Insights in Diabetic Foot Infection. World Journal of Diabetes. 2011;2(2): 24-32.

9. Sulistianingsih, Dirk YP, Runtuboi, Lucky VW. Sensitivitas antibiotik terhadap bakteri yang diisolasi dari ulkus diabetika di RSUD Abepura. Kota Jayapura. Jurnal Biologi Papua. 2014;6(2): 53-9.

10. Akbar G, Tiara, Karimi J, Anggraini D. Pola bakteri dan resistensi antibiotik pada ulkus diabetik grade dua di RSUD Arifin Achmad periode 2012. Riau: JOM. 2014;1(2):1-15.

11. Wikansari NH, Retno, Budi R. Pemeriksaan total kuman udara dan Staphylococcus aureus di ruang rawat inap rumah sakit $X$ kota Semarang. Jurnal Kesehatan Masyarakat. 2012;1(2):384-92.

12. Sutjahjo A. Kuman dan uji kepekaan antibiotik di kaki diabetic. Indonesian Journal of Clinical Pathologi and Medical Laboratory. 2012; 20(1): 20-4.

13. Kahuripan AR, Andrajati, Syahfridani T. Analisis pemberian antibiotik berdasarkan uji sensitivitas terhadap pencapaian clinical outcome pasien infeksi ulkus diabetika di RSUD Dr. H. Abdul Moelek Lampung. Majalah IImu Kefarmasian. 2009;6(2):75-87.

14. Banashankari GS, Rudresh HK, Harsha AH. Prevalence of gram negative bacteria in diabetic foot- a clinico-microbiological study. Al Ameen J Med Sci. 2012;5(3):224-32.

15. Windriya DP, Sutjahjo S, Hermina N. Profil data pasien diabetes melitus tipe 2 dengan komplikasi ulkus diabetikum di RSU Dr. Soetomo Surabaya tahun 2012. JIMKI. 2013;2(1):7-12.

16. Yohana ELG, Erly, Elmatris SY. Pola resistensi bakteri aerob pada ulkus diabetik terhadap beberapa antibiotika di laboratorium mikrobiologi RSUP Dr. M. Djamil Padang tahun 2011-2013. Jurnal Kesehatan Andalas. 2017;6(1):164-70.

17. Ozer B, Kalaci A, Semerci E, Duran N, Davul S. Infections and aerobic bacterial pathogens in diabetic foot. African Journal of Microbiological Research. 2010;4:2153-60. 
18. Mehta VJ, Kikani KM, Mehta SJ. Microbiological profile of diabetic foot ulcers and its antibiotics susceptibility pattern in a teaching hospital Gujarat. International Journal of Basic \& Clinical Pharmacology. 2014.3(1): 92-5.

19. Pappu AK, Sinha A, Johnson A. Microbiological profile of diabetic foot ulcer. Calicut Medical Journal. 2011;9(3):e2.

20. Febrianto AW, Mukaddas A, Faustine I. Rasionalitas penggunaan antibiotik pada pasien infeksi saluran kemih (ISK) di instalasi rawat inap RSUD Undata Palu tahun 2012. Natural Science. 2013;2(3):20-9. 